\title{
Anti-Sperm Antibodies: Prevalence of Ig A and Ig G Positive Serology among Infertile Patients in Kisangani, Democratic Republic of Congo
}

\author{
Mike-Antoine Maindo Alongo ${ }^{*}$, Juakali Sihalikyolo', Salomon Batina Agasa ${ }^{2}$, \\ Antoine Modia O'yandjo', Bernard Mbutu³, Gédéon Katenga Bosunga1, \\ Jean-Pascal Manga Okenge ${ }^{1}$
}

\footnotetext{
${ }^{1}$ Department of Obstetrics and Gynecology, Faculty of Medicine, University of Kisangani, Kisangani, Democratic Republic of Congo ${ }^{2}$ Department of Internal Medicine, Faculty of Medicine, University of Kisangani, Kisangani, Democratic Republic of Congo ${ }^{3}$ Intitut Superieur des Techniques Médicales de Kisangani, Ema Esu Laboratory, Kisangani, Democratic Republic of Congo Email: *maindo21@gmail.com
}

How to cite this paper: Maindo A, M-A, Sihalikyolo, J., Agasa, S.B., O'yandjo, A.M., Mbutu, B., Bosunga, G.K. and Okenge, J.-P.M. (2019) Anti-Sperm Antibodies: Prevalence of Ig A and Ig G Positive Serology among Infertile Patients in Kisangani, Democratic Republic of Congo. Open Journal of Obstetrics and Gynecology, 9, 707-714.

https://doi.org/10.4236/ojog.2019.95070

Received: March 24, 2019

Accepted: May 21, 2019

Published: May 24, 2019

Copyright $\odot 2019$ by author(s) and Scientific Research Publishing Inc. This work is licensed under the Creative Commons Attribution International License (CC BY 4.0).

http://creativecommons.org/licenses/by/4.0/

(c) (i) Open Access

\begin{abstract}
Introduction: Infertility in a couple is a stressful situation. Among the causes is the presence of antisperm antibodies that play a harmful role in reducing fertility and negatively influencing in vitro fertilization. The aim of this study is to determine their prevalence among infertile patients in Kisangani. Patients and methods: We conducted an analytical cross-sectional study in health facilities in the city of Kisangani. Of the 1379 patients who consulted for conception, 311 were tested for antisperm antibodies by ELISA. Results: Of the 311 patients, 121 tested positive (38.91\%). Women were significantly more likely to be positive (p-value $=0.013$ ). Ig G was positive in $32.48 \%$ of patients and Ig A in 10.93\%. Age was a significant predictor of the number of positive patients (p-value $<0.001$ ). Compared to patients of $\leq 30$ years of age, having 31 to 40 years of age or 41 years of age and older increased respectively 2 and 3 times the risk of being positive. In secondary infertility, women are twice as likely to be positive. Conclusion: The prevalence of antisperm antibodies is very high among infertile patients in Kisangani with predominance among women. Older age increases the risk of positivity. This test should therefore be integrated into infertility investigations as often as possible.
\end{abstract}

\section{Keywords}

Antisperm Antibody, Immune Infertility, Unexplained Infertility, Democratic Republic of Congo 


\section{Introduction}

Infertility is a disease defined as the absence of clinical conception after 12 months or more of unprotected sexual intercourse, satisfactory in quantity and quality and at appropriate times or after insemination treatment using donor semen [1] [2] [3]. Not conceiving can lead to stress, depression, discrimination, ostracism etc. [4] [5]. This situation is worse in Africa where children are considered a source of wealth.

In Africa, the prevalence of infertile couples varies enormously from one region to another and even within the same region, reaching $30 \%-40 \%$ in some regions [6] [7] [8]. A study conducted in Kasai, southern Democratic Republic of Congo (DRC), in 2010 reported a prevalence of $11 \%$ [9].

After evaluation of the infertile couple, in $30 \%$ of cases, the responsibility is exclusively female, in $30 \%$ exclusively male and in $30 \%$, the responsibility belongs to the couple while in $10 \%$, no cause is objective [10]. In the DRC, Juakali and Labama [11] in Kisangani found that $57.5 \%$ of men consulting for conception had a pathological spermogram while for women, Kalume et al. [12] in Goma found that in $67.6 \%$ of cases, tubal pathologies were found and in $38.1 \%$, the causes were multifactorial. According to the American Society of Reproductive Medicine, in nearly $15 \%-30 \%$ of couples, no cause will be found after a standard exploration of infertility [13]. Faced with the unexplained infertility dilemma, studies have been conducted for decades to investigate the immunological factors that may explain infertility. Already in 1922, Meaker [14] reported the presence of cytotoxic factors for sperm in the serum of 2 infertile women. And since then, several studies have been conducted and have highlighted antisperm antibodies (ASA) and their role in the occurrence of infertility [15]-[21]. Immunoglobulins G, A and M (Ig G, Ig A and Ig M) are essentially implicated in the occurrence of infertility in the sense that they may be responsible for a decrease in motility and cervical penetration of sperm as well as their interaction with the oocyte and even the development of the embryo [22].

Hamadaaa et al. [23] showed that a remarkable percentage (about 40\%) of infertile couples without a serious cause of infertility had circulating antibodies capable of agglutinating spermatozoa. These antibodies can be found in the blood, seminal plasma, sperm and cervical mucus.

The presence of Ig $\mathrm{G}$ and Ig A or Ig M alone or IgA alone is associated with a reduced fertilization rate and influences the results of in vitro fertilization (IVF). The specific effect depends on the subtypes of ASA [22]. Despite the different results of the role of anti-sperm antibodies in infertility, there is a failure to take into account the search for ASA when managing infertility.

In DRC, in the city of Kisangani, some doctors have recently begun to look for ASA when assessing infertility, however, there are no studies describing the prevalence of anti-sperm antibodies in our country.

The aim of this study is therefore to determine the prevalence of positive serology for ASA among infertile couples in the city of Kisangani. 


\section{Patients and Method}

During the period of 2 years, from 1 January 2017 to 31 December 2018, we conducted an analytical cross-sectional study on 1379 patients who consulted 7 health facilities in Kisangani City (Cliniques Universitqires de Kisangani, Makiso-Kisangani General Referral Hospital, Kabondo General Referral Hospital, HCKis, CELPA Hospital Centre, Reverend Mokili Hospital and COKIS Health Centre) for conception. Of these, we selected 311 patients in whom the search for circulating ASA in serum was performed. A part from that, their medical files should have all data needed for this paper. For ASA search, approximately 5 $\mathrm{ml}$ of the venous blood from each of the 311 patients was collected under an aseptic condition. For the separation of serum from whole blood, a centrifugation at $3000 \mathrm{rpm}$ was performed for 5 minutes. Once the serum was obtained, the analysis was performed immediately. If this was not possible, the sample was kept in a sterile tube at a temperature of $2^{\circ} \mathrm{C}-8^{\circ} \mathrm{C}$ until the time of analysis. The immunoglobulin test was performed by ELISA using the Stat Fax ${ }^{\otimes} 4700$ device. All the tests were carried out in the Ema Esu laboratory, the only one carrying out this test in the city.

Positive patients were compared to the negatives one. Variables studied were age, gender and type of infertility.

Data were collected from medical and laboratory files were encoded using Excel. We used Epi Info ${ }^{\circledR}$ software version 7.2 for data analysis.

\section{Results}

During our study, we found that the prevalence of positive serology for ASA was $38.91 \%$. This prevalence was higher among women (44\%) than men $(29.27 \%)$ with a statistically significant difference (p-value $=0.0133)$. Ig $\mathrm{G}$ was the most commonly found antibody (32.48\%) with no statistically significant difference found ( $\mathrm{p}$-value $=0.1263$ ). Ig A was positive in $17.36 \%$ of cases (Table 1 ).

As Table 2 shows us, having an age between 31 and 40 years or $\geq 41$ years respectively multiplied by 2 or almost 3 the risk of having positive ASA serology compared to those having $\leq 30$ years of age. However, there was no statistically significant difference between patients aged 31 - 40 years and those aged 41 years and over. The Likelihood ratio test indicated that age was a significant predictor (p-value $=0.0000)$ of the number of ASA positive patients among infertile patients.

Taking into account the type of infertility (Table 3), we found no statistically significant difference between the 2 sexes while considering the presence of ASA during primary infertility ( $\mathrm{p}$-value $=0.4815$ ). During secondary infertility, women are significantly more likely to have positive ASA serology ( $\mathrm{p}$-value $=$ 0.0388) with twice as much risk than men.

\section{Discussion}

Infertility has often been described as one of the most prevalent chronic diseases 
at any age [24]. Immunological infertility is one of the main causes of infertility through the production of antibodies against sperm and, in terms of conception failure, has become a serious health problem affecting approximately 1 in 5 couples of childbearing age [21] [25].

Table 1. ASA positive Serology and sexe of patients.

\begin{tabular}{ccccc}
\hline & $\begin{array}{c}\text { Female } \\
\mathrm{N}=200\end{array}$ & $\begin{array}{c}\text { Male } \\
\mathrm{N}=111\end{array}$ & $\begin{array}{c}\text { Total of 2 sexes } \\
\mathrm{N}=311\end{array}$ & p-value \\
\hline Type of positive Ig & $\mathrm{n}(\%)$ & $\mathrm{n}(\%)$ & $\mathrm{n}(\%)$ & \\
Ig A & $35(17.50)$ & $19(17.12)$ & $54(17.36)$ & 0.9319 \\
Ig G & $71(35.50)$ & $30(29.03)$ & $101(32.48)$ & 0.1263 \\
Ig A and Ig G & $18(9.00)$ & $16(14.41)$ & $34(10.93)$ & 0.1426 \\
Ig A and/or Ig G & $88(44.00)$ & $33(29.72)$ & $121(38.91)$ & 0.0133 \\
\hline
\end{tabular}

Table 2. ASA positive Serology and age of patients.

\begin{tabular}{|c|c|c|c|c|}
\hline & $\begin{array}{c}\text { Positive Ig A } \\
\text { and/or Ig G } \\
\text { n (\%) }\end{array}$ & $\begin{array}{c}\text { Negative Ig A } \\
\text { and Ig G } \\
\text { n (\%) }\end{array}$ & $\mathrm{p}$-value & OR (CI 95\%) \\
\hline \multicolumn{5}{|c|}{ Group I of comparison } \\
\hline$\geq 41$ years & $46(65.71)$ & $46(39.32$ & 0.0004 & $2.9583(1.5955-5.4851)$ \\
\hline$\leq 30$ years & $24(34.29)$ & $71(60.68)$ & & \\
\hline \multicolumn{5}{|c|}{ Group II of comparison } \\
\hline$\geq 41$ years & $46(47.42)$ & $46(38.66)$ & 0.1949 & $1.4314(0.8315-2.4639)$ \\
\hline $31-40$ years & $51(52.58)$ & $73(61.34)$ & & \\
\hline \multicolumn{5}{|c|}{ Group III of comparison } \\
\hline $31-40$ years & $51(68.00)$ & $73(50.69)$ & 0.0142 & $2.0668(1.1515-3.7095)$ \\
\hline$\leq 30$ years & $24(32.00$ & $71(49.31)$ & & \\
\hline
\end{tabular}

Likelihood ratio test, $\mathrm{p}$-value $<0.001$.

Table 3. ASA positive Serology and type of infertility.

\begin{tabular}{|c|c|c|c|c|}
\hline & $\begin{array}{c}\text { Positive Ig A } \\
\text { and/or Ig G n (\%) }\end{array}$ & $\begin{array}{l}\text { Negative Ig A or } \\
\text { Ig G n (\%) }\end{array}$ & p-value & OR (CI 95\%) \\
\hline \multicolumn{5}{|c|}{$\begin{array}{l}\text { Primary infertility } \\
\qquad(\mathrm{N}=146)\end{array}$} \\
\hline Male & 19 (27.94) & 49 (72.06) & 0.4815 & $\begin{array}{c}1.2895 \\
(0.6348-2.6193)\end{array}$ \\
\hline Female & $26(33.33)$ & $52(66.67)$ & & \\
\hline \multicolumn{5}{|c|}{$\begin{array}{l}\text { Secondary Infertility } \\
\qquad(\mathrm{N}=165)\end{array}$} \\
\hline Male & $14(32.56)$ & $29(67.44)$ & 0.0388 & $\begin{array}{c}2.1405 \\
(1.0315-4.4415)\end{array}$ \\
\hline Female & $62(50.82)$ & $60(49.18)$ & & \\
\hline
\end{tabular}


The prevalence of ASA positive serology varies widely around the world. In the world, studies have shown that ASA serology is positive in $1 \%-36 \%$ of infertile couples [20] [25] [26] [27] [28]. In Africa, Emad M Siam et al. [29] in Egypt and B.I. Adejuno et al. [30] in Nigeria found $20 \%$ and $28.2 \%$ respectively. In our study, of the 311 infertile patients in whom ASA serology was performed, 121 had ASA positive serology representing 38.91\% of cases. Some authors agree that the prevalence of ASA varies significantly depending on the type of examination used for ASA research, but also the number of antibodies sought in patients and the location [28] [31]. In addition, other authors have found that during infections, patients can develop ASA by antigenic community between germs and sperm [32] [33]. The city of Kisangani being at the crossroads of provinces having a high rate of STIs [34] [35], this may therefore justify the high prevalence of ASA in Kisangani, as infections are among causes of ASA.

When comparing the prevalence of ASA in both sexes, it was significantly higher among women (44\%) than among men $(29.27 \%)$ (p-value $=0.0133)$. In India, Tripti $\mathrm{N}$ et al. [36] found seroprevalence of $39.19 \%$ in men and $40 \%$ in women.

In terms of Ig type, Ig G was the most commonly found antibody (32.48\%). Ig A was positive in $17.36 \%$ of cases. Karimi F et al. [31] found positive serology in $8.2 \%$ of infertile patients for Ig G and $8.2 \%$ also for Ig A. As explained before, we think that the type of laboratory procedure can explain the difference.

In relation to the age of the patients, we found that being between 31 and 40 years of age or $\geq 41$ years of age increased the risk of having positive ASA serology by a factor of 2 or almost 3 respectively compared to being 30 years of age. However, there was no statistically significant difference between patients aged 31 to 40 and those aged 41 and over. The Likelihood ratio test indicated that age was a significant predictor ( $\mathrm{p}$-value $<0.001$ ) of the number of ASA positive patients among infertile patients. Hossain A and Col [28] also made the same observation.

Taking into account the type of infertility, we found no statistically significant difference between the 2 sexes while considering the presence of ASA during primary infertility ( $\mathrm{p}$-value $=0.4815$ ) whereas during secondary infertility, women were significantly more likely to have positive ASA serology ( $\mathrm{p}$-value = 0.0388) with 2 times risk compare to men. In their study, Tripti $\mathrm{N}$ et al. [36] also found that among primary infertility cases, women were significantly more likely to be positive than men at secondary infertility with $21.36 \%$ versus $10.43 \%$.

\section{Conclusion}

The prevalence of antisperm antibodies is very high in infertile Kisangani patients with predominance among women. Older age increases the risk of positivity. This test should therefore be integrated into infertility investigations as often as possible. 


\section{Conflicts of Interest}

The authors declare no conflicts of interest regarding the publication of this paper.

\section{References}

[1] Practice Committee of the American Society for Reproductive Medicine (2013) Definitions of Infertility and Recurrent Pregnancy Loss: A Committee Opinion. Fertility Sterilty, 99, 63. https://doi.org/10.1016/j.fertnstert.2012.09.023

[2] WHO-ICMART (2009) International Committee for Monitoring Assisted Reproductive Technology (ICMART) and the World Health Organization (WHO) Revised Glossary of ART Terminology. Fertility Sterilty, 92, 1520-1524. https://doi.org/10.1016/j.fertnstert.2009.09.009

[3] Larsen, U. (2005) Research on Infertility: Which Definition Should We Use? Fertility Sterilty, 83, 846-852. https://doi.org/10.1016/j.fertnstert.2004.11.033

[4] Chachamovich, J.R., Chachamovich, E., Ezer, H., Fleck, M.P., Knauth, D., et al. (2010) Investigating Quality of Life and Health-Related Quality of Life in Infertility: A Systematic Review. Journal of Psychosomatic Obstetrics \& Gynecology, 31, 101-110. https://doi.org/10.3109/0167482X.2010.481337

[5] Bahamondes, L. and Makuch, M.Y. (2014) Infertility Care and the Introduction of New Reproductive Technologies in Poor Resource Settings. Reproductive Biology and Endocrinology, 12, 87. https://doi.org/10.1186/1477-7827-12-87

[6] Umeora, O.U., Mbazor, J.O. and Okpere, E.E. (2007) Tubal Factor Infertility in Benin City, Nigeria-Sociodemographics of Patients and Aetiopathogenic Factors. Tropical Doctor, 37, 92-94. https://doi.org/10.1177/004947550703700211

[7] Owolabi, A.T., Fasubaa, O.B. and Ogunniyi, S.O. (2013) Semen Quality of Male Partners of Infertile Couples in Ile-Ife, Nigeria. Nigerian Journal of Clinical Practice, 16, 37-40. https://doi.org/10.4103/1119-3077.106729

[8] Leke, R.J., Oduma, J.A., Bassol-Mayagoitia, S., Bacha, A.M. and Grigor, K.M. (1993) Regional and Geographical Variations in Infertility: Effects of Environmental, Cultural, and Socioeconomic Factors. Environmental Health Perspectives, 101, 73-80. https://doi.org/10.1289/ehp.93101s273

[9] Mubikayi, M.L., Mubikayi, N.N. and Kalengo, M.K. (2010) Stérilité du couple à l'institut Médicale chrétien du Kasaï. Annales Africains de Médecine, 3, 426-431.

[10] Inhorn, M.C. (2003) Global Infertility and the Globalization of New Reproductive Technologies: Illustrations from Egypt. Social Science \& Medicine, 56, 1837-1851. https://doi.org/10.1016/S0277-9536(02)00208-3

[11] Juakali, S.K.V. and Labama, L. (2009) Analyse du sperme dans la stérilité du couple à Kisangani. KisMéd, 4, 7-15.

[12] Kalume, M.A., Labama, L., Sergio, C. and Stone, S. (2014) Profil clinique et étiologique de l’infertilité féminine à Goma. KisMéd, 5, 31-43.

[13] Practice Committee of the American Society for Reproductive Medicine (2006) Optimal Evaluation of the Infertile Female. Fertility and Sterility, 86, S264-S267. https://doi.org/10.1016/j.fertnstert.2006.08.041

[14] Meaker, S.R. (1922) Some Aspects of the Problem of Sterility. Boston Medical and Surgical Journal, 187, 535-539. https://doi.org/10.1056/NEJM192210121871503

[15] Franklin, R.R. and Dukes, C.D. (1964) Antispermatozoal Antibody and Unexplained Infertility. American Journal of Obstetrics \& Gynecology, 89, 6-9. https://doi.org/10.1016/S0002-9378(16)35035-9 
[16] Wang, X.-W., Ding, G.-R., Shi, C.-H., Zeng, L.-H., Liu, J.-Y., Li, J., Zhao, T., Chen, Y.-B. and Guo, G.-Z. (2010) Mechanisms Involved in the Blood-Testis Barrier Increased Permeability Induced by EMP. Toxicology, 276, 58-63. https://doi.org/10.1016/j.tox.2010.07.003

[17] Huo, Y., Xu, Y., Wang, J., Wang, F., Liu, Y., Zhang, Y. and Zhang, B. (2015) Analysis of the Serum Reproductive System Related Autoantibodies of Infertility Patients in Tianjin Region of China. International Journal of Clinical and Experimental Medicine, 8, 14048-14053.

[18] Hossain, A., Islam, N., Aryal, S. and Madanes, A. (2007) The Prevalence of Circulating Anti Sperm Antibody (ASA) in Infertile Population Representing of All Etiologies. Middle East Fertility Society Journal, 12, 27-30.

[19] Liu, M.-M., Liu, L., Chen, L., Yin, X.-J., Liu, H., Zhang, Y.-H., Li, P.-L., Wang, S., Li, X.-X. and Yu, C.-H. (2017) Sleep Deprivation and Late Bedtime Impair Sperm Health through Increasing Antisperm Antibody Production: A Prospective Study of 981 Healthy Men. Medical Science Monitor, 23, 1842-1848. https://doi.org/10.12659/MSM.900101

[20] Anas, L.Y., Ahmad, L.Y. and Basha, W.S. (2016) The Epidemiology of Anti-Sperm Antibodies Among Couples with Unexplained Infertility. Journal of Clinical and Diagnostic Research, 10, QC01-QC03. https://doi.org/10.7860/JCDR/2016/15788.7380

[21] Brazdova, A., Senechal, H., Peltre, G. and Poncet, P. (2016) Immune Aspects of Female Infertility. International Journal of Fertility and Sterility, 10, 1-10.

[22] Lu, J.-C., Huang, Y.-F. and Lu, N.-Q. (2008) Antisperm Immunity and Infertility. Expert Review of Clinical Immunology, 4, 113-126. https://doi.org/10.1586/1744666X.4.1.113

[23] Hamadaa, A., Estevesb, S.C. and Agarwal, A. (2012) Unexplained Male Infertility-Looking beyond Routine Semen Analysis. European Urological Review, 7, 90-96.

[24] Smith, S., Pfeifer, S.M. and Collins, J.A. (2003) Diagnosis and Management of Female Infertility. The Journal of the American Medical Association, 290, 1767-1770. https://doi.org/10.1001/jama.290.13.1767

[25] Collins, J.A., Burrows, E.A., Yeo, J. and Young-Lai, E.V. (1993) Frequency and Predictive Value of Antisperm Antibodies among Infertile Couples. Human Reproduction, 8, 592-598. https://doi.org/10.1093/oxfordjournals.humrep.a138102

[26] Peters, A.J. and Coulam, C.B. (1992) Sperm Antibodies. American Journal of Reproductive Immunology, 27, 156-162. https://doi.org/10.1111/j.1600-0897.1992.tb00743.x

[27] Krapez, J.A., Hayden, C.J., Rutherford, A.J. and Balen, A.H. (1998) Survey of the Diagnosis and Management of Antisperm Antibodies. Human Reproduction, 13, 3363-3367. https://doi.org/10.1093/humrep/13.12.3363

[28] Hossain, A., Islam, N., Aryal, S. and Madanes, A. (2007) The Prevalence of Circulating Antisperm Antibody (ASA) in Infertile Population Representing of All Aetiologies. Middle East Fertility Society Journal, 12, 27-30.

[29] Siam, E.M. and Hefzy, E.M. (2011) The Relationship between Antisperm Antibodies Prevalence and Genital Chlamydia trachomatis Infection in Women with Unexplained Infertility. Middle East Fertility Society Journal, 15, 93-100. https://doi.org/10.1016/j.mefs.2011.09.003

[30] Adejumo, B.I., Oke, A.A., Emokpae, M.A., Oyeleke, A.A., Erhobor, T.A., Agba, M.I. and Oni, A. (2014) A Study of Anti-Sperm Antibody among Infertile Subjects In- 
vestigates for Infertility in Lagos, Nigeria. Annals of Biomedical Engineering, 13, 29-34.

[31] Karimi, F., Khazaei, S. and Alaedini, F. (2008) Serum Antisperm Antibodies in Fertile and Infertile Individual. Iranian Journal of Medical Sciences, 33, 88-93.

[32] Parida, R. and Samanta, L. (2017) In Silico Analysis of Candidate Proteins Sharing Homology with Streptococcus Agalactiae Proteins and Their Role in Male Infertility. Systems Biology in Reproductive Medicine, 63, 15-28. https://doi.org/10.1080/19396368.2016.1243741

[33] Thaper, D. and Prabha, V. (2018) Molecular Mimicry: An Explanation for Autoimmune Diseases and Infertility. Scandinavian Journal of Immunology, 88, e12697. https://doi.org/10.1111/sji.12697

[34] Bassandja, J.O., Botwafine, M., Katawandja, A.L., Agasa, S.B. and Likwela, J.L. (2014) Séroprévalence de la syphilis chez les donneurs bénévoles de sang à Kisangani, RDC. KisMéd, 5, 82-85.

[35] Katenga, B.G. and Maindo, A.M.-A. (2014) Syphilis au cours de la grossesse dans la ville de Kisangani: Prévalence, Facteurs de risque et pronostic de la grossesse. KisMéd, 5, 22-30.

[36] Tripti, N., Patra, P.K. and Prakash, S.J. (2011) Evaluation of Serum Antisperm Antibodies in Infertility. The Journal of Obstetrics and Gynecology of India, 61, 307-316. https://doi.org/10.1007/s13224-011-0034-7 